Article

\title{
Epidemiological profile of American tegumentary leishmaniasis in the municipality of Manhuaçu, state of Minas Gerais, Brazil
}

\author{
Darlan Gabriel de Lima ${ }^{1}$, Laís Perígolo Mol ${ }^{2}$, Abel Perígolo Mol, \\ Tiago Mendonça de Oliveira ${ }^{3}$, Cristina Mara Teixeira ${ }^{4}$
}

\begin{abstract}
A serious public health problem, American Tegumentary Leishmaniasis (ATL) is a widely distributed anthropozoonosis caused by protozoa Leishmania spp. This study aimed to evaluate the profile of human cases of cutaneous leishmaniasis Americana in Manhuaçu, MG from 2010 through 2015. A descriptive, retrospective and ecological study of the confirmed cases of ATL was carried out based on age, sex, place of dwelling, type of entry (new diagnosis or recurrence), and clinical form of the disease as recorded in the Brazilian system of notifiable disease Sistema de Informação de Agravos de Notificação (SINAN). The first quarter of the years higher witnessed the highest numbers of notifications. All 58 notifications corresponded to new diagnoses, most of which in the cutaneous form (95\%), in males $(76 \%)$, in inhabitants of the rural area (86\%), and in people aged $20-59$ years old (60\%). Thus, the epidemiological profile of ATL in Manhuaçu indicates that males aged between 20 and 59 years old and living in rural areas are more likely to get infected. The epidemiological profile of ATL is an important step to promote adequate health surveillance and prevent the disease in the region.
\end{abstract}

Keywords: american tegumentary leishmaniasis, SINAN, rural areas, epidemiology

\footnotetext{
1 Faculdade do Futuro - FAF Sociedade de Ensino Superior de Manhuaçu Curso de Ciências Biológicas, Manhuaçu, Brazil.

2 Prefeitura Municipal de Manhuaçu, Manhuaçu, Brazil.

3 Departamento de Medicina Veterinária Preventiva/Escola de Veterinária da Universidade Federal de Minas Gerais (DMVP/EV-UFMG), Belo Horizonte, Minas Gerais, Brazil.

${ }^{4}$ Ministério da Agricultura Pecuária e Abastecimento (DIPOA), Brasília, Brazil.

* Corresponding author: Escola de Veterinária da UFMG, Laboratório de Epidemiologia - Av. Antônio Carlos 6627, campus Pampulha da UFMG - CEP 31270-901 - Tel: +5531986587122 E-mail: tiago0725@gmail.com
} 


\section{Introduction}

American Tegumentary Leishmaniasis (ATL) is a widely distributed zoonotic disease affecting people from several regions, such as the Americas, the Mediterranea, Central and West Asia, including the Middle East, which accounts for one-third of the cases reported (ALVAR et al., 2012). A serious public health problem, ATL is caused by protozoa Leishmania spp. and is characterised by severe skin and mucosal injury (DA-SILVA; CUNHA, 2007; BRASIL, 2009; GOSCH et al., 2017).

LTA has a wide spectrum of clinical manifestations due to both the varied immunological response across individuals and the different Leishmania species (ALMEIDA; SANTOS, 2011; VIANA et al., 2013), but three major clinical conditions stand out: Cutaneous Leishmaniasis (CL), Mucosal Leishmaniasis (ML), and Muco-Cutaneous Leishmaniasis (MCL) (NAME et al., 2005). Additionally, there is a less frequent form of ATL is related to the absence of lesions, but with alteration of the lymphatic system in some individuals (MARZOCHI; MARZOCHI, 1994).

CL is characterized by a painless ulcerative or nodular lesion in commonly exposed areas of the skin. In Brazil, CL can be caused by different Leishmania spp., $L$. brasiliensis, $L$. amazonensis and $L$. guyanensis (BRASIL, 2013), and its manifestations range of single or multiple cutaneous tegumentary lesions, internal mucosal lesions and glandular leishmaniasis (MARZOCHI; MARZOCHI, 1994). ML, which is mostly caused by $L$. brasiliensis, is often characterised by a destructive mucosal inflammation (BRASIL, 2013). When both CL and ML unfold concomitantly, their association is called MCL, which is characterised by multiple lesions through the body.

ATL, as one of the major zoonotic diseases in the Americas, has been reported from the South of the United States of America to the North of Argentina (SILVA et al., 2012). Due to the increased number of ATL cases 
worldwide, the WHO has considered it a major parasitic-infectious disease (NAME et al., 2005). However, ATL is a notifiable disease in only 32 out of the 88 countries where it is prevalent (NEVES, 2011).

In Brazil, leishmaniasis is a notifiable disease within the first 180 days upon diagnosis. All cases are recorded in the SINAN (Sistema de Informação de Agravos de Notificação), a federal agency for epidemiological surveillance that has been gradually implemented since 1993 (BRASIL, 2007). Leishmaniasis has been the second most reported vector-borne protozoan disease throughout Brazil, accounting for an average of 26 thousand cases per year from 1998 through 2007 (DA-SILVA; CUNHA, 2007; BRASIL, 2013).

The protozoan transmission has epidemiological patterns that can be classified according to human interaction with the vector habitat. Phlebotomine sand flies, such as Nyssomyia spp. and Lutzomyia spp. from the family Psychodidae (subfamily Phlebotominae), are Leishmania vectors in the Americas and play an important role in disease dissemination among humans and domestic animal reservoirs (DE SOUZA et al., 2015). Wild transmission occurs in areas of primary vegetation - being an enzootia of wild animals, affecting only humans who visit this environment (BRASIL, 2017). Human occupational and leisure activities related to the transmission of ATL include the exploitation of wild areas for resource extraction, land use and occupation, agricultural and tourist activities. Additionally, the place of dwelling is associated with ATL, due to uncontrolled land occupation, deforestation, presence of the vector and the human presence near secondary forests or forest residues (BRASIL, 2013). Notwithstanding, the ATL epidemiological profile in Brazil has been changing due to the recent climate and environmental changes (DE AGUIAR et al., 2014).

In the State of Minas Gerais (MG), leishmaniasis has been reported since 1940, with prevalence in rural and peri-urban areas (NASCIMENTO et 
al., 2013). However, there have been constant outbreaks in urban areas and in rainforest regions throughout the state (VALE and FURTADO, 2005).

In the view of recent changes, new studies are required to inform the current epidemiological profile of leishmaniasis in the State of Minas Gerais. This study in particular aims to report and evaluate the recent cases of leishmaniasis in the Municipality of Manhuaçu from 2010 through 2015.

\section{Methods}

\section{Area of study}

The study was conducted in the Municipality of Manhuaçu $\left(20^{\circ} 15^{\prime} 29^{\prime \prime}\right.$ $\mathrm{S}, 42^{\circ} 02^{\prime}$ 01" W), Minas Gerais countryside, within the mesoregion named Zona da Mata (IBGE, 2017a). The municipality has an area of $628.318 \mathrm{~km}^{2}$ and a total population of 79,574 (IBGE, 2017b). It neighbours the following municipalities: Caputira, Luisburgo, Simonésia, Santa Barbara Do Leste, Vermelho Novo, Matipó, São João Do Manhuaçu, Manhumirim, Reduto, and Raul Soares (ALMG, 2017).

\section{Database}

This is a descriptive, ecological and retrospective study of confirmed cases of American Cutaneous Leishmaniasis that took place from 2010 through 2015 in the Municipality of Manhuaçu. It is built on the analysis of a secondary database made available through the System of Notifiable Diseases (DATASUS, 2017) developed by the Brazilian Ministry of Health and the Brazilian Institute of Geography and Statistics (IBGE, 2017B). Data were transferred and assessed using Microsoft Office Excel 2016® software (Microsoft, 2016). 
Data analysis was performed using the deductive method with the support of further information retrieved from the literature (NEGRÃO; FERREIRA, 2014). The following variables were used to profile the disease in this study: age, sex, place of dwelling, type of entry during hospital admission (new diagnosis or recurrence), and clinical manifestations. Additionally, the disease incidence per age group was calculated with a view to gaining a better understanding of its distribution in the period.

\section{Results}

A total of 58 cases of ATL were reported in Manhuaçu from 2010 through 2015, i.e., 9.67 cases per year on average (Table 1). The highest numbers of diagnoses took place in the first quarter of the years.

Table 1 - Monthly frequency of ATL notifications in Manhuaçu, 2010-2015.

\begin{tabular}{cccccccc}
\hline & \multicolumn{7}{c}{ Year of diagnosis } \\
\hline Month of diagnosis & 2010 & 2011 & 2012 & 2013 & 2014 & 2015 & Mean \\
\hline January & 2 & 4 & 0 & 0 & 2 & 1 & 1,5 \\
\hline February & 2 & 4 & 2 & 1 & 0 & 0 & 1,5 \\
\hline March & 1 & 3 & 0 & 0 & 0 & 2 & 1 \\
\hline April & 1 & 0 & 0 & 0 & 0 & 0 & 0,17 \\
\hline May & 0 & 1 & 0 & 0 & 0 & 0 & 0,17 \\
\hline June & 0 & 1 & 2 & 0 & 0 & 2 & 0,83 \\
\hline July & 1 & 1 & 0 & 0 & 1 & 1 & 0,67 \\
\hline August & 2 & 3 & 0 & 0 & 0 & 2 & 1,17 \\
\hline September & 1 & 2 & 0 & 0 & 1 & 1 & 0,83 \\
October & 1 & 0 & 0 & 0 & 2 & 1 & 0,67 \\
November & 0 & 0 & 0 & 0 & 1 & 1 & 0,33 \\
\hline December & 2 & 1 & 0 & 1 & 1 & 0 & 0,83 \\
\hline Total & 13 & 20 & 4 & 2 & 8 & 11 & 9,67 \\
\hline
\end{tabular}

Table 2 shows the figures for sex, place of dwelling and clinical manifestation. All 58 notifications corresponded to new diagnoses: 95\% (55 cases) CL, and 5\% (3 cases) ML. Most cases affected males (76\%) and (24\%) of cases in females. It was found that $86.2 \%$ of ATL infections occurred in 
rural residents (50 cases). One case (1.8\%) took place in the peri-urban area, and $7(12 \%)$ cases occurred in the urban area. An analysis crossing sex and place of dwelling shows a frequency of $65.5 \%$ in males and $20.7 \%$ in females living in rural areas and the other cases occurred in other areas (13.8\%).

Table 2 - Descriptive data of the ATL notifications in Manhuaçu, 2010-2015, according to area, sex and clinical form.

\begin{tabular}{c|c|c}
\hline & Cases (n) & Frequency (\%) \\
\hline Sex & \multicolumn{2}{|c}{} \\
Male & 44 & 76 \\
Female & 14 & 24 \\
& Clinical form & \\
Cutaneous (CL) & & 95 \\
Mucosal (ML) & 55 & 5 \\
\hline Place of dwelling & 3 & \\
& & \\
Rural & & \\
Urban & & \\
Peri-urban & 50 & 12 \\
Total & 7 & 1,8 \\
& 58 & $100 \%$ \\
\hline
\end{tabular}

In an analysis of notifications per age group, the highest incidence was found for those aged 40-59 (34\%), followed by those aged 20-39 years old (26\%) (Figure 1). The remaining were distributed as follows: 14 cases (24\%) in the age group of $0-19$ years, 8 cases (14\%) in the age group of 60-79 years, and 1 case (2\%) in the over 80 age group. The number of males outnumbered that of females in all age groups. 
Figure 1 - Distribution of ATL notifications per age group and sex, in Manhuaçu, 2010-2015.

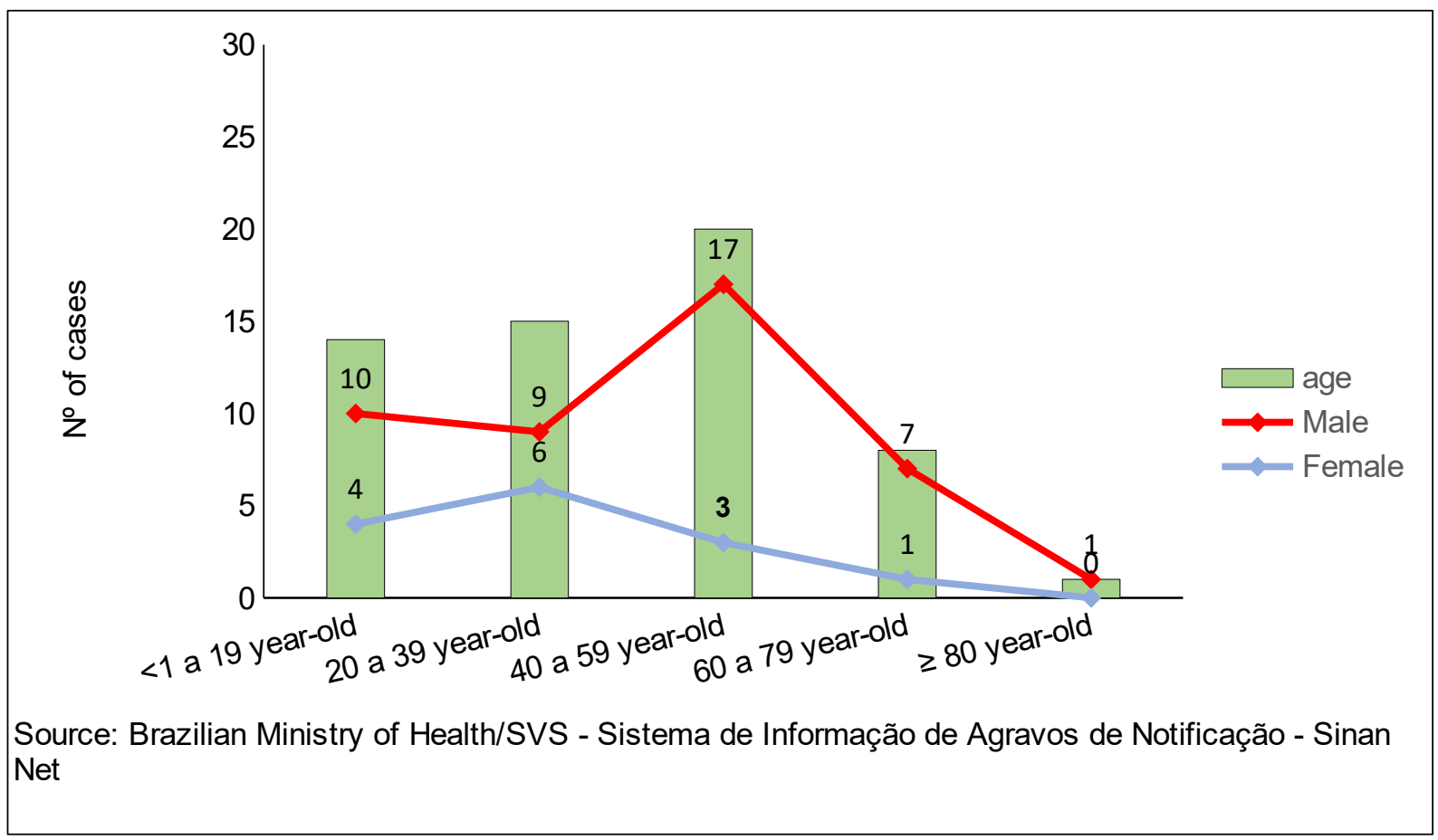

The incidence of ATL per 10.000 inhabitants was calculated for the period (Table 3) based on data provided by IBGE (2010). A higher incidence of ATL was found in individuals aged 40 to 59 years old (11.27 cases per 10.000 hab.), followed by those older than 60 years.

Table 3 - Incidence of ATL per number of inhabitants in Manhuaçu, 2010-2015.

\begin{tabular}{ccc}
\hline Age Group & Population* & $\begin{array}{c}\text { Incidence } \\
\text { (per 10.000 inhab.) }\end{array}$ \\
\hline$<1$ to 19 y.o. & 27.240 & 5.13 \\
20 to 39 y.o & 26.515 & 5.65 \\
40 to 59 y.o. & 17.738 & 11.27 \\
$\geq 60$ y.o. & 8.081 & 11.13 \\
Total & 79.574 & 7.28 \\
\hline
\end{tabular}

* IBGE (2010). 


\section{Discussion}

A higher incidence of ATL was found in the first quarter of the years under scrutiny. This period coincides with the rainy season in the region, when the high temperature and humidity levels favour the reproduction of phlebotomine sandflies (NIKONAHAD et al., 2017; OVALLOS, 2011). Lemos and Lima (2005) reported that some sandflies species are specifically found during this time.

The data also showed that most infections occurred in the rural areas, where people are usually close to secondary vegetation and remaining forests, which also favours the disease transmission (BRASIL, 2013, MELO et al., 2017). Leishmaniasis is endemic in Brazil, and the close proximity of populations in the rural areas to the wildlife, especially mammals, makes it a broader reservoir for the parasite (PASSOS et al., 1993). Nevertheless, transmission can also be linked to domesticated animals or to people from urban areas who work in the field (TEMPONI et al., 2018).

The parasite-host relationship is a complex and multifactorial issue (BRASIL, 2017), and the diversity of reservoirs for Leishmania sp. includes wild, domesticated and synanthropic animals, as well as canids, felids, marsupials, xenarthrans, chiropters, rodents, and equids. Further studies are necessary to fully understand the role of reservoirs in the transmission in Manhuaçu.

According to Basano and Camargo (2004), the ATL infection profile in the peri-urban areas is linked to places of 'old colonization', such as Manhuaçu. The low number of notifications in this particular area may indicate some inconsistency in the data provided by SINAN. It is possible that people from peri-urban areas were classified as being originally from rural areas. In contrast, Soares et al. (2014) reported that active transmission of leishmaniasis is linked to deforestation in the outskirts of 
urban areas. Therefore, the low occurrence in peri-urban areas may be justified by the classification of the place of dwelling wrong.

This study confirms the higher incidence of ATL in people aged 20 to 59 years, this result is similar to those found by Melo et al. (2017). The high percentage of cases in this age group and male individuals is related to the work performed in rural areas. Manhuaçu is considered among the six largest coffee producers in the country, so the working population in rural areas is in environments with the highest reproduction of the vector (BORGES et al., 2009; IBGE, 2017b). The research by De Araújo et al. (2016) and Melchior et al. (2017) demonstrate that cases of ATL occur in this age group and in males, as it is the economically active people who work in rural areas most likely to be infected. A higher incidence of ATL is observed in people older than 40 years old, what is partially in agreement with Melo et al. (2017) and Temponi et al. (2018). These findings point to a need for a more tight epidemiological surveillance aimed at preventing the disease in people in the risk group. Besides, a more thorough investigation is necessary to identify the actual sandflies species in the region and gain a better understanding of the animals that serve as reservoir for the parasite.

As the data provided by SINAN came from a secondary database, a limitation for this study is the likely occurrence of undernotification, which can bias the findings. Temponi et al. (2018) reported that analysing individual data is not possible in ecological studies, what may pose a vulnerability to the study (i.e., ecological fallacy).

\section{Conclusion}

The main epidemiological profile of ATL in Manhuaçu from 2010 through 2015 consists of males aged 20-59 years old from rural areas. This finding seems to suggest that ATL transmission is related to occupational activities within rural areas in the municipality, which is one of the top six 
coffee producers in Brazil and highly economically dependent on agriculture and pasture. Still, further studies are necessary to confirm this correlation.

ATL is a neglected tropical disease, and understanding its epidemiological profile and context may help shed light on which actions to take in order to tackle this disease, especially in a population that depends on rural activities. Furthermore, the method used in the present study can be applied to other areas interested in understanding and monitoring ATL as well as in acting on prevention.

\section{References}

ALMEIDA O.L.S.; SANTOS J.B. Avanços no tratamento da leishmaniose tegumentar do novo mundo nos últimos dez anos: uma revisão sistemática da literatura. Anais Brasileiros de Dermatologia, Rio de Janeiro, v.86, n.3, p.497-506, 2011. https://doi.org/10.1590/S0365-05962011000300012

ALMG. ASSEMBLÉIA LEGISLATIVA DE MINAS GERAIS. Municípios de Minas Gerais. Disponível em:

$<$ http://www.almg.gov.br/consulte/info sobre minas/index.html? aba=js tabMunicipios\&sltMuni=395>. Acesso em: 20 de maio de 2017.

ALVAR J.; VÉLEZ I.D.; BERN C.; HERRERO M.; DESJEUX P.; CANO J. et al. Leishmaniasis worldwide and global estimates of its incidence. PLoS One, California, v.7, n.5, p.1-12, 2012. https://doi.org/10.1371/journal.pone.0035671

BORGES B.K.A.; SILVA J.A.; HADDAD J.P.A.; MOREIRA E.C.; MAGALHÃES D.F.; RIBEIRO L.M.L.; FIÚZA V.O.P. Presença de animais associada ao risco de transmissão da leishmaniose visceral em humanos em Belo Horizonte, Minas Gerais. Arquivos Brasileiro de Medicina Veterinária e Zootecnia, Belo Horizonte, v.61, n.5, p.1035-1043, 2009. https://doi.org/10.1590/\$0102-09352009000500004 
BRASIL. Ministério da Saúde. Secretaria de Atenção à Saúde. Departamento de Atenção Básica. Vigilância em saúde: zoonoses. Ministério da Saúde, Secretaria de Atenção à Saúde, Departamento de Atenção Básica. Cadernos de Atenção Básica; n. 22 - Brasília: Ministério da Saúde, 2009. 228 p. Disponível em: $<$ http://189.28.128.100/dab/docs/publicacoes/cadernosab/abcad22.pdf $>$. Acesso em: 10 abr. 2017

BRASIL. Ministério da Saúde. Secretaria de Vigilância em Saúde. Departamento de Vigilância Epidemiológica. Manual de Vigilância da Leishmaniose Tegumentar Americana. Ministério da Saúde, Secretaria de Vigilância em Saúde, Departamento de Vigilância Epidemiológica. - 2. ed. atual., 3. reimpr. - Brasília: Editora do Ministério da Saúde, 2013. 180 p. Disponível em: $<$ http://bvsms.saude.gov.br/bvs/publicações/manual_vigilancia_leishmaniose_tegum e ntar_americana_2edicao.pdf>. Acesso em: 10 mai. 2017

BRASIL. Ministério da Saúde. Secretaria de Vigilância em Saúde. Departamento de Vigilância Epidemiológica. Sistema de Informação de Agravos de Notificação Sinan: normas e rotinas. Ministério da Saúde, Secretaria de vigilância em Saúde, Departamento de Vigilância Epidemiológica. - 2. Ed. - Brasília: Editora do Ministério da Saúde, 2007. 68 p. Disponível em: < http://bvsms.saude.gov.br/bvs/publicacoes/sistema informacao agravos notificacao sinan.pdf>. Acesso em: 12 mai. 2017

Brasil. Ministério da Saúde. Secretaria de Vigilância em Saúde. Departamento de Vigilância das Doenças Transmissíveis. Manual de vigilância da leishmaniose. Ministério da Saúde, Secretaria de Vigilância em Saúde, Departamento de Vigilância das Doenças Transmissíveis. - Brasília: Ministério da Saúde, 2017. 189p.

DA-SILVA, L. M. R.; CUNHA, P. R. A urbanização da leishmaniose tegumentar americana no município de Campinas - São Paulo (SP) e região: magnitude do problema e desafios. Anais Brasileiros de Dermatologia, Rio de Janeiro, v.82, n.6, p. 515-519, 2007. https://doi.org/10.1590/S0365-05962007000600003 
DATASUS. Departamento de Informática do SUS. Informações de saúde (TABNET): Epidemiológicas e morbidade. Disponível em: < http://www2.datasus.gov.br/DATASUS/index.php? area $=0203 \& i d=29892200 \& V O b j=h t t p: / /$ tabnet.datasus.gov.br/cgi/deftohtm.exe? sinannet/cnv/lta>. Acesso em: 20 de maio de 2017.

DE AGUIAR, G.M.; DE AZEVEDO A.C.R.; DE MEDEIROS W.M.; ALVES J.R.C.; RENDEIRO, V. Aspects of the ecology of phlebotomines (Diptera: Psychodidae: Phlebotominae) ina na área of cutaneous leishmaniasis occurrence, municipality of Angra dos Reis, coast of Rio de Janeiro State, Brazil. Revista Do Instituto De Medicina Tropical De São Paulo, São Paulo, v.56, n.2, p. 143-9, 2014. https://doi.org/10.1590/S0036-46652014000200010

DE ARAUJO A.R.; PORTELA N.C.; FEITOSA A.P.S.; DA SILVA O.A.; XIMENES R.A.A.; ALVES L.C.; BRAYNER F.A. Risk factors associated with American Cutaneous Leishmaniasis in an endemic area of Brazil. Revista Do Instituto De Medicina Tropical De São Paulo, São Paulo, v.58, p.1-6, 2016. https://doi.org/10.1590/s1678-9946201658086

DE SOUZA C.F.; BRAZIL R.P.; BEVILACQUA P.D.; ANDRADE J.D. The phlebotomine sand flies fauna in Parque Estadual do Rio Doce, Minas Gerais, Brazil. Parasites \& Vectors, n.8, 619, 2015. https://doi.org/10.1186/s13071-015$\underline{1227-1}$

GOSCH C.S.; MARQUES C.P.; RESENDE B.S.; SOUZA J.D.; ROCHA R.A.D.; LOPES D.S.S.; GOSCH M.S.; DIAS F.R.; DORTA M. L. American tegumentary leishmaniasis: epidemiological and molecular characterization of prevalent Leishmania species in the State of Tocantins, Brazil, 2011-2015. Revista Do Instituto De Medicina Tropical De São Paulo, São Paulo, v.59, p.1-11, 2017. https://doi.org/10.1590/s1678-9946201759091 
IBGE (A). INSTITUTO BRASILEIRO DE GEOGRAFIA E ESTATÍSTICA. Divisão Regional do Brasil em mesorregiões e microrregiões geográficas. Rio de Janeiro: IBGE, v.1, 1990. Disponível em:

$<$ https://biblioteca.ibge.gov.br/visualizacao/monografias/GEBIS\%20\%20RJ/DRB/ Divisao\%20regional_v01.pdf>. Acesso em: 12 maio de 2017.

IBGE (B). INSTITURO BRASILEIRO DE GEOGRAFIA E ESTATÍSTICA. Censo Demográfico 2010: Características urbanísticas e do entorno dos domicílios. Disponível em:

<http://www.ibge.gov.br/home/estatistica/populacao/censo2010/entorno/ default entorno.shtm>. Acesso em: 20 de maio de 2017.

LEMOS, J. C.; LIMA, S. C. Leishmaniose tegumentar americana: flebotomíneos em área de transmissão no Município de Uberlândia, MG. Revista da Sociedade Brasileira de Medicina Tropical, Uberaba, v.38, n.1, p.22-26, 2005. https://doi.org/10.1590/S0037-86822005000100005

MARZOCHI, M. C. A.; MARZOCHI, K. B. F. Tegumentary and Visceral Leishmaniases in Brazil - Emerging Anthropozoonosis and Possibilities for Their Control. Cadernos de Saúde Pública, Rio de Janeiro, v.10, p.359-375, 1994. https://doi.org/10.1590/S0102-311X1994000800014

MELCHIOR L.A.K.; BRILHANTE A.F.; CHIARAVALLOTI-NETO, F. Spatial and temporal distribution of American cutaneous leishmaniasis in Acre state, Brazil. Infectious Diseases of Poverty, v.6, n.99, p.1-9, 2017.

https://doi.org/10.1186/s40249-017-0311-5

MELO H.A.; ROSSONI D.F.; TEODORO U. Spatial distribution of cutaneous leishmaniasis in the state of Parana, Brazil. Plos One, California, v.12, n.9, p.1-10 2017. https://doi.org/10.1371/journal.pone.0185401

MICROSOFT Corporation Office / Excel 2016. Planilha eletrônica Excel. Portland: Microsoft Research 2016. 
NAME R.Q.; BORGES T.K.; NOGUEIRA L.S.C.; SAMPAIO J.H.D.; TAUIL P.L.; SAMPAIO R.N.R. Estudo clinico, epidemiológico e terapêutico de 402 pacientes com leishmaniose tegumentar americana atendidos no Hospital Universitário de Brasília, DF, Brasil. Anais Brasileiros de Dermatologia, Rio de Janeiro, v.80, n.3, p.249-54, 2005. https://doi.org/10.1590/S0365-05962005000300004

NASCIMENTO B.W.L.; SARAIVA L.; NETO R.G.T.; MEIRA P.; SANGUINETTE C.D.; TONELLI G.B.; BOTELHO H.A.; BELO V.S.; DA SILVA E.S.; GONTIJO C.M.F.; ANDRADE J.D. Study of sand flies (Diptera: Psychodidade) in visceral and cutaneous leishmaniasis areas in central western of Minas Gerais state - Brazil. Acta Tropica, v.125, p.262-268, 2013. https://doi.org/10.1016/j.actatropica.2012.11.005

NEGRÃO, G. N.; FERREIRA, M.E.M.C. Considerações sobre a leishmaniose tegumentar Americana e sua expansão no território brasileiro. Revista Percurso, Maringá, v.6, n.1, p. 147- 168, 2014. https://doi.org/10.4025/revpercurso.v6i1.21375

NEVES, D.P. Parasitologia humana. 12a . Ed., São Paulo: Atheneu, 2011.

NIKONAHAD A.; KHORSHIDI A.; GHAFFARI H.R.; AVAL H.E.; MIRI M.; AMARLOEI A.; NOURMORADI H.; MOHAMMADI A. A time series analysis of environmental and metrological factors impact on cutaneous leishmaniasis incidence in an endemic area of Dehloran, Iran. Environmental Science and Pollution Research, v.24, n.16, p.14117-14123, 2017. https://doi.org/10.1007/s11356-017-8962-0

OVALLOS, F. G. Estudo da capacidade vetorial de Migonemyia migonei (França) e de Pintomyia fischeri (Pinto) (Diptera: Psychodidae) para Leishmania (Leishmania) infantum chagasi Cunha \& Chagas. 2011. 107 p. Dissertação (Mestrado em Saúde Pública). Faculdade de Saúde Pública, Universidade de São Paulo, São Paulo. 
PASSOS V.M.; FALCÃO, A.L.; MARZOCHI, M.C.; GONTIJO, C.M.; DIAS, E.S.; BARBOSA-SANTOS, E.G.; et al. Epidemiological aspects of American cutaneous leishmaniasis in a periurban area of the metropolitan region of Belo Horizonte, Minas Gerais, Brazil. Memórias do Instituto Oswaldo Cruz, v.88, p.103-110, 1993. https://doi.org/10.1590/S0074-02761993000100016

SOARES, M.E. DA C.; PEDROSA-SILVA, A.L.; SÁ E ROCHA, L.; LIMA, N.L.; VERLI, F.D.; FERREIRA, F. DE O.; et al. Epidemiological profile of individuals with American cutaneous leishmaniasis in Jequitinhonha Valley, Brazil. Eastern Mediterranean Health Journal, v.19, Suppl 3, S81-S88, 2014. https://doi.org/10.26719/2013.19.Supp3.S81

SILVA, R. A.; MERCADO, V. T. C.; HENRIQUES, L de F.; CIAVORO, R. M. de C.; WANDERLEY, D. M. V. Magnitude e tendência da Leishmaniose Tegumentar Americana no Estado de São Paulo, Brasil, 1975 a 2008. Revista Brasileira de Epidemiologia, São Paulo, v.15, n.3, p.617-626, 2012. https://doi.org/10.1590/S1415$\underline{790 X 2012000300015}$

TEMPONI A.O.D.; DE BRITO M.G.; FERRAZ M.L.; DINIZ S.D.; DA CUNHA T.N.; SILVA M.X. American tegumentary leishmaniasis: a multivariate analysis of the spatial circuits for production of cases in Minas Gerais State, Brazil, 2007 to 2011. Cadernos de Saúde Pública, Rio de Janeiro, v.34, n.2, p.1-14, 2018. https://doi.org/10.1590/0102-311x00165716

VIANA A.G.; MAYRINK W.; FRAGA C.A.C.; SILVA L.M.; DOMINGOS P.L.B.; BONAN P.R.F.; DE-PAULA A.M.B.; BOTELHO A.C.C. Histopathological and immunohistochemical aspects of American cutaneous leishmaniasis before and after different treatments. Anais Brasileiros de Dermatologia, Rio de Janeiro, v.88, n.1, p.32-40, 2013. https://doi.org/10.1590/S0365-05962013000100003

VALE E.C.S.; FURTADO T. Leishmaniose tegumentar no Brasil: revisão histórica da origem, expansão e etiologia. Anais Brasileiros de Dermatologia, Rio de Janeiro, v.80, n.4, p.421-428, 2005. https://doi.org/10.1590/S0365-05962005000400015 